\title{
First GB records of the invasive Asian shore crab, Hemigrapsus sanguineus from Glamorgan, Wales and Kent, England
}

\author{
BECKY SEELEY ${ }^{1}$, JACK SEWELL ${ }^{1}$ AND PAUL F. CLARK ${ }^{2}$ \\ ${ }^{1}$ The Marine Biological Association of the United Kingdom, The Laboratory, Citadel Hill, Plymouth, PL1 2PB, Devon, UK, \\ ${ }^{2}$ Invertebrates Division, Department of Life Sciences, The Natural History Museum, Cromwell Road, London SW7 5 BD, UK
}

\begin{abstract}
The present contribution reports on the capture of two adult male specimens of the Asian/Japanese shore crab, Hemigrapsus sanguineus (de Haan, 1835) from Glamorgan, south Wales and Kent, southern England. These represent the first records of this species from mainland Great Britain.
\end{abstract}

Keywords: Asian shore crab, Japanese shore crab, Hemigrapsus sanguineus, invasive species, South Wales, southern England

Submitted 8 June 2015; accepted 9 June 2015

\section{INTRDDUCTIDN}

The Asian shore crab (also referred to as the Japanese shore crab), Hemigrapsus sanguineus (de Haan, 1835) is a native species of the North-West Pacific coast with a recorded distribution from China (Hong Kong), Taiwan, Korea, Russia and Japan (Sakai, 1976; Dai et al., 1986; Dai \& Yang, 1991). This crab was first reported outside of its native area by Williams \& McDermott (1990) when a live ovigerous specimen was hand-collected in Townsend Inlet, Cape May County, New Jersey, $39^{\circ} 07^{\prime} 06^{\prime \prime} \mathrm{N} 74^{\circ} 43^{\prime} \mathrm{oo}^{\prime \prime} \mathrm{W}$, United States, on the 24 September 1988. By 1990, a breeding population was established (McDermott, 1991). The current United States distribution is from Cape Cod, Massachusetts in the north to Oregon Inlet, North Carolina, in the south (McDermott, 1998b). Breton et al. (2002) recorded Hemigrapsus sanguineus from Europe for the first time, citing established populations at Le Havre, France and Oosterschelde, The Netherlands, while d'Udekem d'Acoz (2006) recorded the crab from Belgium. Later, Dauvin (2009a, b; Dauvin \& Dufossé, 2011) reported upon the dispersal of the Asian shore crab westwards along the French/English Channel coast from Le Havre to the Cotentin Peninsular, and Lord (2010) mentioned populations in Guernsey and Jersey. European dispersal eastwards now includes the coast from Berck-Authie to Dunkirk, Opal Coast of France (Dauvin et al., 2009; Gothland et al., 2013), additional Dutch populations (Faasse, 2004; Nijland \& Faasse, 2005) and $\sim 20$ specimens, including one female, were discovered on the coast of Lower Saxony, Germany by Obert et al. (2007). In 2011, Gothland et al. (2013) recorded densities of up to $101 \pm 19$ ind. $\mathrm{m}^{-2}$ on the French coast at La Hougue. Recently, Landschoff et al. (2013) confirmed a well-established population in the Wadden Sea, with the most northerly European record being Romo Island,

Corresponding author:

J. Sewell

Email: jase@mba.ac.uk
Denmark. Confirmation by email (personal communication, 9 September 2014, to P.F. Clark from Jonas Geburzi, Zoologisches Museum, Universitat zu Kiel) states that on 15 March 2012, Karsten Reise (AWI Wadden Sea Station in List on Sylt) found numerous specimens of Hemigrapsus sanguineus and Hemigrapsus takanoi in Havneby Harbour, Romo Island, but they were not present at this locality in 2011. Furthermore, in the same email it is reported that Christian Buschbaum (AWI Wadden Sea Station in List on Sylt) found Hemigrapsus sanguineus at the harbour of Fano, an island off Esbjerg, Denmark on 8 July 2012.

Isolated individual male crabs have been reported elsewhere in Europe from Croatia, the Adriatic Sea (Schubart, 2003), Romania and the Black Sea by Micu et al. (2010); these were captured in August 2001 and on 27 August 2008, respectively. Hemigrapsus sanguineus has also been reported from the UK crown dependencies of Guernsey and Jersey, the Channel Islands, however, until now the species had not been recorded from Great Britain. Recently, Roy et al. (2014) considered which invasive alien species were most likely to impact on native biodiversity, but were not yet established in the wild in Great Britain and a 'Horizon Scanning Workshop' was established. Hemigrapsus sanguineus was identified as posing a 'high risk' (see Roy et al., 2014: Table 2) based on the likelihood of impact and establishment, and the likelihood of arrival in the next ten years. The paper presented here is to report the sightings of individual adult male specimens of Hemigrapsus sanguineus from Glamorgan, south Wales and Kent, southern England.

\section{MATERIALS, METHODS AND RESULTS}

A male specimen of Hemigrapsus sanguineus was handcollected in the intertidal zone, grid ref. STo20662, near Aberthaw B Power Station, Aberthaw, Glamorgan, South Wales on 2 May 2014 by Martin Burke. Two adequate 
photographs (Figures $1 \& 2$ ) were taken of the crab. The dorsal view photograph (Figure 1) taken of the specimen is of a crab with conspicuous eyes, a squarish carapace bearing three teeth on the anterolateral margin and an almost-straight front divided into two shallow lobes = Hemigrapsus. The photograph of the ventral view (Figure 2) shows a fleshy vesicle at the base of the right cheliped dactylus (see Breton et al., 2002, Figure $2 \mathrm{~A}$ ) and the suborbital stridulation organ is a finely striated crest (see Breton et al., 2002, Figure 2A) not divided into three unequal parts (see Breton et al., 2002, Figure $2 \mathrm{~B}$ ); the dorsal photograph shows the pereiopods (walking legs) with a distinctive pattern of light and dark stripes. From these two photographs, the crab can be identified as $H$. sanguineus.

Photographs were submitted to the mitten crab recording scheme (http://www.mittencrabs.org.uk). The recorder was aware it was not Eriochier sinensis but was unable to identify the specimen and was seeking identification assistance. At the same time, copies of the photographs were also submitted to the Non-Native Species Secretariat and the Marine Biological Association's Sealife Survey Facebook page for confirmation of identification.

A Non-Native Species alert notice was immediately circulated for this specimen to various stakeholders. The rapid alert was made possible due to the presence of an active invasive species recording scheme. Additionally, the crab was found by an enthusiastic member of the public who took positive action to record the find. The specimen was left in situ by the recorder, but no further specimens have been found in subsequent surveys of the area undertaken by Natural Resources Wales and National Museum Wales staff.

A second male specimen was captured on three occasions on the intertidal rocky grounds at the end of Hampton Jetty $\left(\sim 51^{\circ} 22^{\prime} 14^{\prime \prime} \mathrm{N} 1^{\circ} 05^{\prime} 53^{\prime \prime} \mathrm{E}\right)$, Herne Bay, Kent, England on 3 April, 12 and 14 May, 2014 by Dean Pearson. The specimen was released on the first two occasions, photographed on 14 May (Figure 3) and then destroyed. The photo was emailed to the GB Non-Native Species Secretariat for identification on 15 May 2014. The photograph (Figure 3) is a dorsal

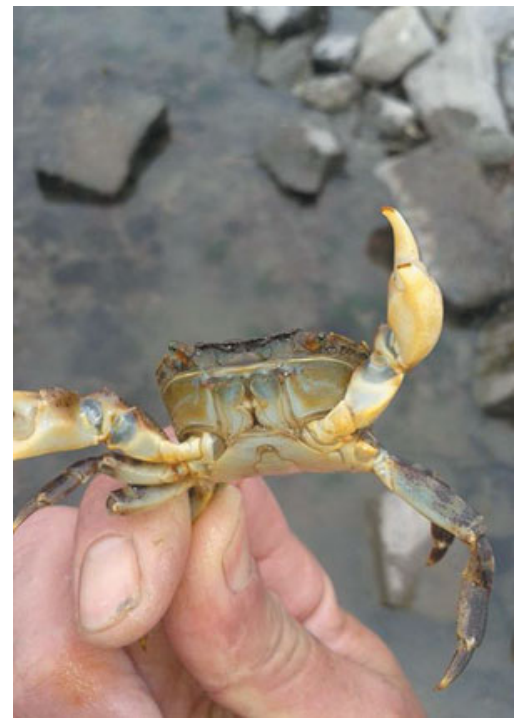

Fig. 2. Hemigrapsus sanguineus: ventral view of the crab from South Wales shows the fleshy vesicle at the base of right cheliped dactylus and the suborbital stridulation organ as a finely striated crest (not divided into three unequal parts). Photo taken by Martin Burke, 2 May 2014.

view that compares well with that from the Glamorgan locality and is also considered to be $H$. sanguineus. Dean Pearson (personal communication, P.F. Clark) searched the limited rocky area several times following the removal of the specimen and found no further individuals, suggesting the repeat capture of a single individual.

Although the photographs provide good evidence of $H$. sanguineus records from Great Britain, unfortunately, no specimens have been preserved and deposited in a national museum to date. An identification sheet has subsequently been produced so that relevant organisations have the information to hand, to verify live specimens collected by the public and to facilitate the deposition of confirmed specimens of Hemigrapsus spp. to museum collections.

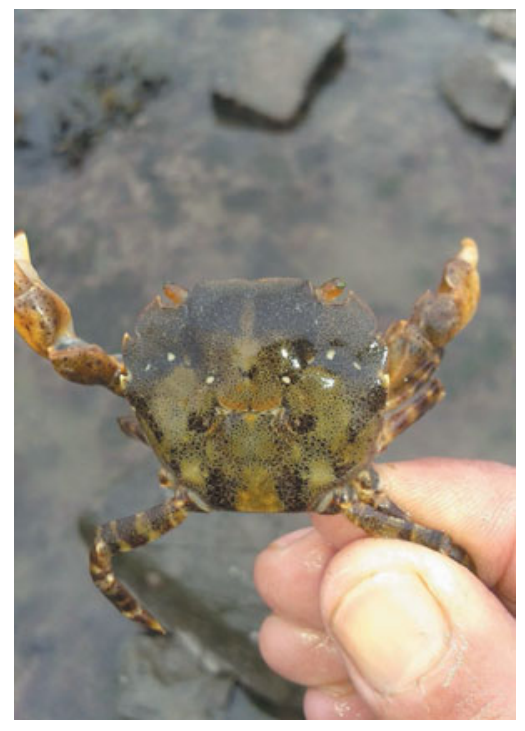

Fig. 1. Hemigrapsus sanguineus: dorsal view of the specimen collected from Glamorgan, South Wales. Photo taken by Martin Burke, 2 May 2014.

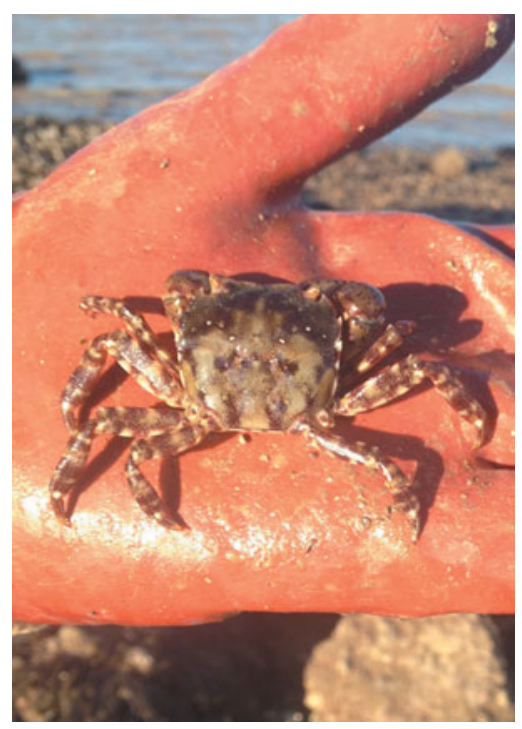

Fig. 3. Hemigrapsus sanguineus collected intertidally from Hampton, Herne Bay, Kent, England. Photo taken by Dean Pearson, 14 May 2014. 


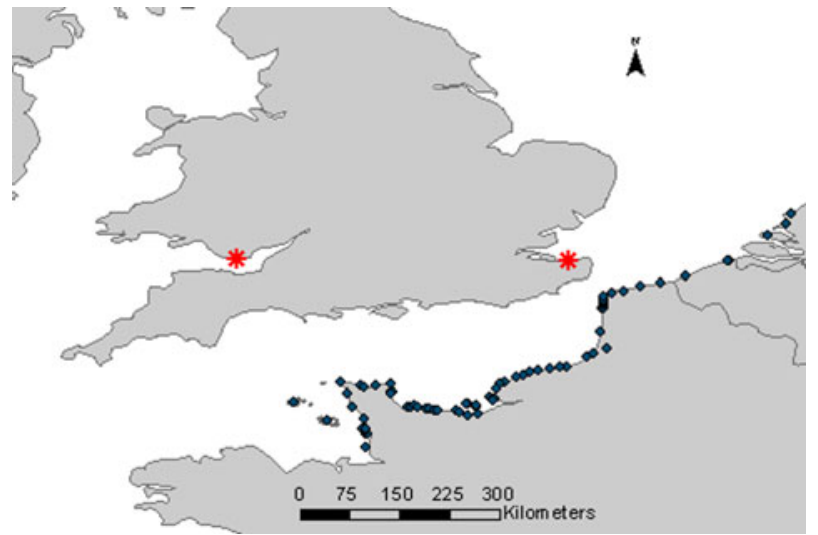

Fig. 4. The location of the two GB sightings in relation to distribution of $H$. sanguineus on the adjacent French, Belgian and Netherlands coasts. Additional records collated from Dauvin et al. (2009), Dauvin \& Dufossé (2011) and R. Lord (personal communication).

\section{DISCUSSION}

In the northern Wadden Sea, the Asian shore crab has survived three consecutive winters (2010-2012) during which ice covered the shore and water temperatures dropped to $-2{ }^{\circ} \mathrm{C}$ (Landschoff et al., 2013). According to Gittenberger et al. (2010), Hemigrapsus sanguineus is also only found at locations with a salinity of $\geq 19$. This species, therefore, can tolerate a wide range of salinities and temperatures. Consequently, there appears to be no temperature or salinity restrictions preventing the extensive establishment of the Asian shore crab along intertidal rocky shorelines and estuaries throughout the British Isles.

Hemigrapsus sanguineus has an extremely effective breeding strategy. The breeding season lasts from May to September and a female can produce $2-4$ batches of eggs, $\sim 50$,ooo eggs per spawning (Fukui, 1988; McDermott, 1998a). However, Landschoff et al. (2013) reported that on the ice-covered shores of the northern Wadden Sea, with water temperatures at $-2^{\circ} \mathrm{C}, H$. sanguineus aggregated, slowly crawling, even with ovigerous females, under boulders at low-tide level. This suggests that the Asian shore crab can be ovigerous all year round in north-east Europe.

Once introduced, dispersal can be rapid, as demonstrated by the fast (two year) establishment of a breeding population in New Jersey, United States, following first detection in 1988 (McDermott, 1991). By 1995, the crab had dispersed more than $650 \mathrm{~km}$ (McDermott, 1998a). Since the first record from Le Havre, France in 1999, H. sanguineus has dispersed over $1200 \mathrm{~km}$ in approximately ten years. This rapid rate of spread is likely to be a consequence of their remarkably adaptive breeding strategy/development cycle and the potential for longshore transport of larvae by the prevailing currents from a single site.

Spread is also likely to have been accelerated by probable multiple introductions by hitchhiking in the hull fouling of coastal shipping. Hemigrapsus sanguineus can cling to surfaces, hide in narrow crevices, travel on ship trunks, in anchor boxes, on ropes and inside ballast water systems (Landschoff et al., 2013). Dispersal by human assistance via the transportation of shellfish, such as mussels and oysters, is also a potential vector. Given the distance between the British records, prevailing currents at both locations and a lack of additional records from the south coast, it is considered extremely unlikely that both specimens originated from the same introduction event.

Minchin et al. (2013) commented that 90 alien species have been recorded from British marine and brackish waters, 31 of which can tolerate reduced salinity. Their results showed that over $64 \%$ of these have established populations. Furthermore, they note that 35 alien species originated from the North Pacific (particularly the North-West Pacific), with $82 \%$ of these having become established in British waters. Minchin et al. (2013) also state that 48 (54\%) of alien species found in British waters were first recorded from the English Channel coastline. Hemigrapsus sanguineus certainly falls within these parameters and, therefore, is very likely to become established in the UK.

While hull fouling and the transport of larvae in ballast water are rated as the most likely vectors for the introduction of $H$. sanguineus into Great Britain, natural dispersal of larvae must also be considered. Dauvin \& Dufossé (2011) state that in the most abundantly colonised sites, the maximal densities per square metre were higher than 100 (i.e. at La Hougue in 2009, and at La Houge, Gatteville and Dunkirk Harbour in 2010). Recently, Landschoff et al. (2013) record that in the Wadden Sea, $H$. sanguineus has become established on artificial-boulder shorelines, with peak densities of $>_{100}$ crabs $\left(>_{5} \mathrm{~mm}\right.$ carapace width) per square metre being attained within 2-3 years of arrival. In such densities, established breeding populations will produce considerable numbers of larvae. According to Hwang et al. (1993), this species has five zoeal stages and one megalopal larval development stage. When reared in the laboratory at $25^{\circ} \mathrm{C}$, the megalop and first crab stage were attained 18 and 31 days after hatching, respectively. However, in practice, English Channel sea temperatures are lower than $25^{\circ} \mathrm{C}$ and larval development will, therefore, take longer, with the result that larval stages may be present in the water column $\sim 4-6$ weeks. The rapid dispersal of $H$. sanguineus along the northeast coastline of Europe has been attributed to the longshore transport of larvae by the prevailing currents from single sites. There seems little evidence to support this theory to date, although it is also possible that this species might populate the southern coast of England via natural dispersal from its non-native range in north-east Europe. Dispersal across the Channel will depend on weather and sea conditions, such as prolonged strong easterly winds, when the larvae have the potential to be transported over great distances, across the English Channel, which at Calais is only $\sim 35.4 \mathrm{~km}$. The above rapid-dispersal scenario of $H$. sanguineus also highlights another major issue: once established, thereafter H. sanguineus is extremely difficult, if not impossible, to eradicate.

These two records highlight the importance of maintaining the profile of non-native species reporting and ensuring that members of the public continue to have accessible ways to submit reports of unusual species.

\section{ACKNDWLEDGEMENT}

The authors would like to thank Martin Burke and Dean Pearson, for passing on their records and providing sufficient photographic evidence of their finds to enable this paper to be written. 


\section{REFERENCES}

Breton G., Faasse M., Noël P. and Vincent T. (2002) A new alien crab in Europe: Hemigrapsus sanguineus (Decapoda: Brachyura: Grapsidae). Journal of Crustacean Biology 22, 184-189.

Dai A.-Y. and Yang S.-L. (1991) Crabs of the China seas. Bejing: China Ocean Press [English Edition].

Dai A.-Y., Yang S.-L., Song Y. and Chen G. (1986) Crabs of Chinese seas. Beijing: China Ocean Press [In Chinese].

Dauvin J.C. (2009a) Establishment of the invasive Asian shore crab Hemigrapsus sanguineus (De Haan, 1835) (Crustacea: Brachyura: Grapsoidea) from the Cotentin Peninsula, Normandy, France. Aquatic Invasions 4, 467-472.

Dauvin J.C. (2009b) Asian shore crabs Hemigrapsus spp. (Crustacea: Brachyura: Grapsoidea) continue their invasion around the Cotentin Peninsula, Normandy, France: Status of the Hemigrapsus population in 2009. Aquatic Invasions 4, 605-611.

Dauvin J.C. and Dufossé F. (2011) Hemigrapsus sanguineus (De Haan, 1835) (Crustacea: Brachyura: Grapsoidea) a new invasive species in European waters: the case of the French English Channel coast (2008-2010). Aquatic Invasions 6, 329-338.

Dauvin J.C., Tous Rius A. and Ruellet T. (2009) Recent expansion of two invasive crabs species Hemigrapsus sanguineus (De Haan, 1853) and H. takenoi Asakura \& Watanabe, 2005 along the Opal coast, France. Aquatic Invasions 4, 451-465, doi: 10.3391/ai.2009.4.3.3.

d'Udekem d'Acoz C. (2006) First record of the Asian shore crab Hemigrapsus sanguineus (De Haan, 1835) from Belgium (Crustacea: Brachyura: Grapsoidea). De Strandvlo 26, 74-82.

Faasse M.A. (2004) Opmars van de blaasjeskrab (Hemigrapsus sanguineus de Haan, 1835) in Nederland. Het Zeepaard 64, 143-144.

Fukui Y. (1988) Comparative studies on the life history of the grapsid crabs (Crustacea, Brachyura) inhabiting intertidal cobble and boulder shores. Publications of the Seto Marine Biological Laboratory $33,121-162$.

Gittenberger A., Rensing M., Stegenga H. and Hoeksema B. (2010) Native and non-native species of hard substrata in the Dutch Wadden Sea. Nederlandse Faunistische Mededelingen 33, 21-76.

Gothland M., Dauvin J.C., Denis L., Jobert S., Ovaert J., Pezy J.P. and Spilmont N. (2013) Additional records and current distribution (2011-2012) of Hemigrapsus sanguineus (De Haan, 1835) along the French Coast of the English Channel. Management of Biological Invasions 4, 305-315.

Hwang S.G., Lee C. and Kim C.H. (1993) Complete larval development of Hemigrapsus sanguineus (Decapoda, Brachyura, Grapsidae) reared in laboratory. Korean Journal of Systematic Zoology 9, 69-86.

Landschoff J., Lackschewitz D., Kesy K. and Reise K. (2013) Globalization pressure and habitat change: Pacific rocky shore crabs invade armored shorelines in the Atlantic Wadden Sea. Aquatic Invasions 8, 77-87, doi: http://dx.doi.org/10.3391/ai.2013.8.1.09.

Lord R. (2010) Asian shore crab, Hemigrapsus sanguineus, reaches shores of Channel Islands. Sustainable Guernsey [online]. Available at: http:// www.sustainableguernsey.info/blog/2010/o4/asian-shore-crab-hemigrapsussanguineus-reaches-shores-of-channel-islands/
McDermott J.J. (1991) A breeding population of the western Pacific crab Hemigrapsus sanguineus (Crustacea: Decapoda: Grapsidae) established on the Atlantic coast of North America. Biological Bulletin (Woods Hole) 181, 195-198.

McDermott J.J. (1998a) The western Pacific brachyuran Hemigrapsus sanguineus (Grapsidae) in its new habitat along the Atlantic coast of the United States: reproduction. Journal of Crustacean Biology 18 , $308-316$.

McDermott J.J. (1998b) The western Pacific brachyuran Hemigrapsus sanguineus (Grapsidae), in its new habitat along the Atlantic coast of the United States: geographic distribution and ecology. ICES Journal of Marine Science 55, 289-298.

Micu D., Niţă V. and Todorova V. (2010) First record of the Japanese shore crab Hemigrapsus sanguineus (de Haan, 1835) (Brachyura: Grapsoidea: Varunidae) from the Black Sea. Aquatic Invasions 5 (Supplement 1), $\mathrm{S}_{1}-\mathrm{S}_{4}$

Minchin D., Cook E.J. and Clark P.F. (2013) Alien species in British brackish and marine waters. Aquatic Invasions 8, 3-19.

Nijland R. and Faasse M. (2005) Meer vindplaatsen van de blaasjeskrab Hemigrapsus sanguineus (de Haan, 1835) in Nederland [More localities for the Asian shore crab Hemigrapsus sanguineus (de Haan, 1835 ) in the Netherlands]. Het Zeepaard 65, 151-152.

Obert B., Herlyn M. and Grotjahn M. (2007) First records of two crabs from the North West Pacific Hemigrapsus sanguineus and H. takanoi at the coast of Lower Saxony, Germany. Wadden Sea Newsletter 2007 , 21-22.

Roy H.E., Peyton J., Aldridge D.C., Bantock T., Blackburn T.M., Britton R., Clark P., Cook E., Dehnen-Schmutz K., Dines T., Dobson M., Edwards F., Harrower C., Harvey M.C., Minchin D., Noble D.G., Parrott D., Pocock M.J.O., Preston C.D., Roy S., Salisbury A., Schönrogge K., Sewell J., Shaw R.H., Stebbing P., Stewart A.J.A. and Walker K.J. (2014) Horizon scanning for invasive alien species with the potential to threaten biodiversity in Great Britain. Global Change Biology 20, 3859-3871, doi: 10.1111/gcb.12603.

Sakai T. (1976) Crabs of Japan and adjacent seas. Tokyo: Kodansha Ltd [in 3 volumes: (1) English text, xxxix + 773 pp., Figures 1-379; (2) Plates volume, 16 pp., Figures 1-251; (3) Japanese text, 461 pp. Figures 1-2]

Schubart C. (2003) The East Asian shore crab Hemigrapsus sanguineus (Brachyura: Varunidae) in the Mediterranean Sea: an independent human-mediated introduction. Scientia Marina 67, 195-200.

and

Williams A. and McDermott J. (1990) An eastern United States record for the western Indo-Pacific crab, Hemigrapsus sanguineus (Crustacea: Decapoda: Grapsidae). Proceedings of the Biological Society of Washington 103, 108-109.

\section{Correspondence should be addressed to:}

J. Sewell

The Marine Biological Association of the United Kingdom The Laboratory, Citadel Hill, Plymouth, PL1 2 $\mathrm{PB}$, Devon, UK email: jase@mba.ac.uk 